\title{
History and Nature of Iron Age Cities in the Northeastern Sea of Galilee Region: A Preliminary Overview
}

David T. Sugimoto

The Society for Near Eastern Studies in Japan (NIPPON ORIENTO GAKKAI) 


\title{
History and Nature of Iron Age Cities in the Northeastern Sea of Galilee Region: A Preliminary Overview
}

\author{
David T. SUGIMOTO*
}

\begin{abstract}
This paper reviews data from archaeological excavations at five key sites in the northeastern region of the Sea of Galilee: Tel Dover, Tel 'En Gev, Tel Hadar, Tel Bethsaida, and Tel Kinrot. Cities were established during Iron Age IB at four out of five of these sites, all of which experienced major changes in their layout at the beginning of Iron Age IIA. The second cities lasted until the end of Iron Age IIB. Iron Age IB cities likely reflect the Kingdom of Geshur, and Iron Age IIA-B cities the southern expansion of Aram Damascus. The material culture of these cities, particularly the architecture, is nonetheless more similar to that of the Aramaean and Neo-Hittite cities in northern Syria than to Canaanite cities in the southern Levant during both periods.
\end{abstract}

Keywords: ‘En Gev, Geshur, Aram Damascus, Israel, city planning

\section{Introduction}

Five known archaeological sites of Iron Age cities are located on the northern and eastern shores of the Sea of Galilee, Israel. They include Tel Dover, Tel 'En Gev, Tel Hadar, Tel Bethsaida, and Tel Kinrot (Map 1). Archaeological excavations have been conducted at all of these sites in recent years.

The aim of this paper is to understand the history and nature of this region as a whole based on the data from these sites. Final reports from excavations of these localities are not yet published, but preliminary results have been reported in various contexts. In addition, between 17-18 March, 2012, an international symposium entitled The Land of Geshur: Archaeological Reconstruction was held at Keio University, Tokyo, where the excavators of these sites gathered and discussed their results. These reports and discussions provide a sound platform on which to begin this study of the general nature and archaeological record of the region. ${ }^{1}$

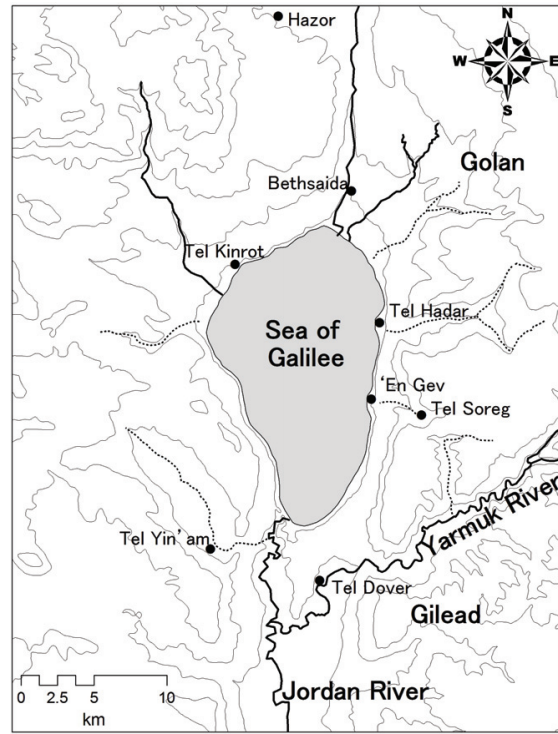

Map 1: Iron Age Sites in the Northeastern Sea of Galilee Region (produced by N. Watanabe) 
The existence of the kingdom of "Geshur" during the early Iron Age is particularly wellknown in this region. Its princess was reportedly married to King David of the newly established kingdom of Israel (Deuteronomy 3:14; Joshua 12:5, 13:2; I Samuel 27:8; II Samuel 3:3), ${ }^{2}$ and their son Absalom later rebelled against David and fled to this area (II Samuel 13:30-39, 15:8). The geographical location and duration of the kingdom of Geshur are debated ${ }^{3}$ and we cannot automatically assume that these five archaeological sites belonged to it. On the other hand, few scholars deny the existence of the kingdom of Geshur in the early Iron Age in the northeastern region of the Sea of Galilee. By examining archaeological data from these sites, we can better understand the history and nature of Geshur.

Furthermore, knowledge of this region at the beginning of the Iron Age is essential for understanding the main geopolitical changes occurring throughout the Levant at that time. Many Canaanite cities collapsed between the twelfth and tenth centuries BC and the new kingdoms of Israel, Aram, Ammon, Moab, and Edom were formed in the following period. Establishment of the kingdom of Geshur likely reflects a similar process and is key to understanding the regional movements of people. ${ }^{4}$

In this paper, we first evaluate the chronological relationship between the five sites mentioned in the introduction, and then analyze the material culture of each chronological horizon. We conclude by reconstructing the history and nature of the whole region and discuss them in relation to the kingdom of Israel.

\section{Stratigraphic Horizons of Iron Age Cities in the Northeastern Sea of Galilee Region 1. Chronological Framework of the Five Main Sites}

This section reviews archaeological research at the five main sites of concern: Tel Dover, Tel 'En Gev, Tel Hadar, Tel Bethsaida, and Tel Kinrot, and then compares their chronological framework. ${ }^{5}$

\footnotetext{
2 This region is thus often called the "Land of Geshur." Late Professor Kochavi of Tel Aviv University conducted the regional "Geshur Project" from the end of the 1980s to the early 2000s (Kochavi 1989; 1992). Kochavi led the excavations at Tel Hadar, Tel 'En Gev, and Tel Soreg on the hill east of Tel 'En Gev. Ben-Ami (1981) once identified Tel Soreg as the city of Aphek recorded in I Kings ch. 20, but the excavations uncovered only meager structures from the ninth and eighth centuries BC; Kochavi (1989, 6-9; 1991, 181) judged it was only a small fortress.

3 The reference to Geshur has also been suggested as early as the fourteenth century BC in the Amarna letters (Albright 1943; B. Mazar et al. 1961) and as late as 838 BC in Shalmaneser III's inscriptions (Na'aman 2012). However, both of these readings are speculative based on reconstructed text, and are not reliable for historical reconstructions (see Pakkala 2010; 2013). On the other hand, very few scholars deny the historical core for King David's marriage to Maacha, daughter of the Geshurite King Talmai, and Absalom's flight to Geshur (e.g., Na'aman 2012, 92; Pakkala 2013, 245). Concerning the location of Geshur, there seem to be two traditions in the Hebrew Bible. Joshua 13:1 and II Samuel 27:8 refer to Geshurites in the south close to the Philistine area, not in the northeast of the Sea of Galilee (see Edelman 1988; Fischer 2004, 135-136). However, the Geshurites are often referred to in connection with the Maachathites (Deuteronomy 3:14; Joshua 12:5, 13:11, 13), and the latter can be clearly set north of the Sea of Galilee, west of the northern Geshur area, particularly in view of the location of Abel Beth-Maacha. W. F. Albright (1956, 12) pointed out that "Gether," mentioned as a descendant of Aram in Genesis 10:23, is an Aramaic pronunciation of Geshur. II Samuel 15:8 has Absalom state that the kingdom of Geshur is in Aram. It is thus more reasonable to locate this particular kingdom of Geshur northeast of the Sea of Galilee.

4 Berlejung (2014, 342-344) points out the similarity between the kingdoms of Aram and those of Israel, Judah, Ammon, Moab, and Edom. They all have a tribal structure, non-urban pastoral background, and are referred to by the others with the expression "bit (the house of) and the name of their eponymous founders (e.g., bit Humri, bit David)" or toponyms as well as the timing of their urbanization. The kingdom of Geshur can be compared to all of these kingdoms, particularly if it was somehow related to the Aramaeans.

The following chronological discussions are in principle based on Modified Conventional Chronology suggested by A. Mazar (2005). For further discussions, see also Sugimoto forthcoming.
} 
Situated in the far southeast region on the northern bank of the Yarmuk River, the settlement of Tel Dover had already been established by the Neolithic-Chalcolithic period (Str. X, IX; see Rapuano 2001). The settlement of Late Bronze Age I was then established (Str. VIII), and following a hiatus of Late Bronze Age II, a new city was formed during Iron Age I (Str. VII). Due to the limited excavation area, most unambiguous structures found at the Iron Age I city were tombs, with the exception of several settlement remains. The settlement did not persist after Iron Age IIA but it was revived during the Hellenistic period (Str. VI).

At Tel 'En Gev, situated centrally on the eastern shore of the Sea of Galilee, no Middle and Late Bronze Age settlements were detected. According to the Keio University's excavation results from Area H, the Iron Age IB city was constructed on virgin soil (Str. KIV; Sugimoto 2010; forthcoming; Sugimoto and Kansha 2010; 2011; 2012; see also B. Mazar et al. 1964; Tsukimoto et al. 2009). Having already been established, this city possessed solid city walls and a public building. In the beginning of Iron Age IIA, the city plan was altered with major earthworks, and a new city was constructed with casemate walls and tripartite pillared buildings (Str. KIII). This city was later rebuilt on a smaller scale, although the basic city layout was maintained and continued until the end of Iron Age IIB (Str. KII). The city walls were likely lost during the last stage. Subsequent settlements of the Persian and Hellenistic periods are also known from this site (Str. $\mathrm{KI})$.

Situated north of Tel 'En Gev, Tel Hadar was first settled during the Late Bronze Age I, which had city walls, a round tower, and domestic quarters (Str. VI; Kochavi 1993; Kochavi and Yadin 2008). After a hiatus during the Late Bronze Age II, a new settlement was constructed during Iron Age I (Str. V and IV). Remains in Str. V consisted of only pits and installations, but the later Str. IV (Iron Age IB) reflects a fully developed city with two ware-houses, two tripartite pillared buildings, and a grain silo. The structures in Str. V were destroyed by fire, and the settlement resumed only during Iron Age IIB (Str. III-I). Str. III and II contain the remains of domestic houses alone, but Str. I yielded remains of a public building built on a Late Bronze Age tower, a fragmentary inscription, and a female figurine with a disk.

The city of Tel Bethsaida was first constructed during Iron Age IIA (Str. VI). This wellestablished settlement had two parallel city walls, a four-chambered gate, bit hilani palace, and granary (Arav and Freund 1995; 1999; 2004; 2009). During Iron Age IIB (Str. V), the general city layout including the walls and gate was maintained, although the modifications to the palace structure may suggest some political change. The settlement waned but continued into Iron Age IIC (Str. IV). Later settlements were also recognized during the Persian, Hellenistic, and Roman periods.

The first occupation at Tel Kinrot is known from (Pottery) Neolithic and Chalcolithic periods (5500-3500 BC). A large city with a defensive wall was detected from the Early Bronze Age II. During the Middle Bronze Age II to Late Bronze Age I (Str. VIII-VII), the city covered the whole extent of the mound and was protected by massive fortifications (Fritz 1990; 1999; Fritz and Münger 2002; Münger et al. 2011). After a hiatus of Late Bronze Age II, a new settlement was established during Iron Age I (Str. VI, early eleventh century BC). It subsequently evolved into a large fortified city (Str. V-IV, Iron Age IB) represented by the entire mound. During Iron Age IIA, the lower city was abandoned and a fortress was built on the northern part of the acropolis 
(Str. III). The fortress was destroyed by the Assyrians during the eighth century BC (Str. II). Immediately thereafter, the so-called Assyrian palace was constructed on a foothill of the acropolis and isolated houses were built on the upper slope of the lower city (Str. I). Later settlements from the Hellenistic, Byzantine, Mamluk, and Ottoman periods are also known.

This chronological review of the five sites clearly reveals commonalities in their development (Chart 1). The first is that all cities except Tel Bethsaida were newly constructed during the Iron Age I, particularly in its later part (Iron Age IB). The city of Tel 'En Gev was initially built on virgin soil during Iron Age IB. Although there was a preparatory stage (Str. VI), the city (Str. V) of Tel Kinrot was established during Iron Age IB after the Late Bronze Age I city (Str. VIII-VII). There was an occupational hiatus during the Late Bronze Age II and probably Iron Age IA. The same holds true for Tel Hadar, and the date of the Iron Age I city (Str. IV) appears contemporaneous with Tel Kinrot Str. V. The excavators of Tel Dover did not divide Iron Age I into phases A and B, but because there was another hiatus during Late Bronze Age II, we assume that the site followed the same course of events. Interestingly, all the cities were established with walls and public buildings from the beginning.

The second common developmental stage involves the major change occurring in these cities at the end of Iron Age IB. Tel Hadar and Tel Dover were destroyed and their settlements ceased to exist. A new city was rebuilt during Iron Age IIA at Tel 'En Gev, but the city layout was completely changed with new walls. The city of Tel Kinrot became much smaller and a new fortress was built on the summit area. The first city at Tel Bethsaida was built at this stage, fortified with massive peripheral walls and a gate.

The third common feature between sites is that Iron Age IIB cities maintained similar natures as Iron Age IIA cities, experiencing destruction. At Tel 'En Gev and Tel Kinrot, the basic city layout continued, but Iron Age IIB cities became smaller. The city at Tel Bethsaida continued to thrive during Iron Age IIB (Str. V) with some modifications. On the other hand, the settlement at Tel Hadar revived somewhat during Iron Age IIB, following an Iron Age IIA hiatus.

The fourth commonality is that these cities were destroyed at the end of Iron Age IIB, most likely by the Assyrians. Only at Tel Bethsaida and Tel Kinrot were small settlements established under Assyrian rule.

\section{Chronological Framework of the Northeastern Sea of Galilee Region}

\section{Cities in the Northeastern Sea of Galilee Region and Kingdom of Geshur}

The overview clarifies that Iron Age IB cities in the northeastern Sea of Galilee region completely differ from those built during Iron Age IIA-B. All but Tel Bethsaida were newly constructed during Iron Age IB. They were then destroyed at the end of the period; even in cases of rebuilding, the city layouts were completely altered.

That these cities were already established during Iron Age IB (mid-eleventh century BC) suggests a different history from that of the Israelite cities, because most of the latter were formed during Iron Age IIA (tenth to mid-ninth centuries BC) or later, after the destruction of Canaanite cities (see Chart 1). 


\begin{tabular}{|c|c|c|c|c|c|c|c|c|c|c|c|}
\hline 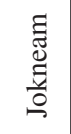 & $>$ & 紊 & & $\begin{array}{l}\bar{x} \\
\overline{\bar{x}}\end{array}$ & $\begin{array}{l}\dot{x} \\
\dot{\bar{x}}\end{array}$ & $\begin{array}{l}\dot{x}^{2} \\
\dot{x} x\end{array}$ & 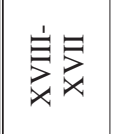 & 1 & $\underset{x}{\sum_{x}^{\infty}}$ & 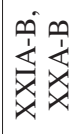 & 㐎: \\
\hline $\begin{array}{l}\frac{0}{7} \\
\frac{0}{50} \\
\sum\end{array}$ & 1 & - & $=$ & ヨ & 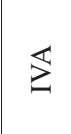 & $\rho^{\infty} \stackrel{\frac{\pi}{1}}{\infty}$ & 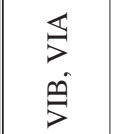 & $\stackrel{\S}{\lessgtr}$ & $\stackrel{\vartheta}{\prime}$ & $\begin{array}{l}\text { 妾 } \\
\underline{x}\end{array}$ & $\begin{array}{l}x \\
\dot{x} \\
\dot{x}^{\prime}\end{array}$ \\
\hline $\begin{array}{l}E \\
\overline{0} \\
\bar{D} \\
\frac{\mathscr{E}}{n}\end{array}$ & ì & $>$ & & 5 & $\begin{array}{l}\stackrel{\Rightarrow}{>} \\
\dot{\equiv}\end{array}$ & $\begin{array}{l}\ddot{x} \\
\dot{x}\end{array}$ & 1 & $\bar{x}$ & $\bar{x}$ & 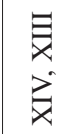 & 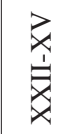 \\
\hline 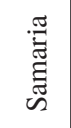 & 1 & 1 & 1 & $\underset{>}{5}$ & $Z_{I}$ & 1 & 1 & | & $\mid$ & 1 & $\mid$ \\
\hline 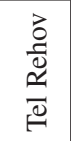 & 1 & 1 & 1 & $\exists$ & $\Xi$ & 站 & 官 & & مُ & $\begin{array}{l}\stackrel{0}{\hat{\circ}} \\
\dot{0} \\
0\end{array}$ & $\overline{\vec{a}}$ \\
\hline 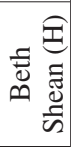 & 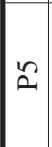 & 1 & | & $\stackrel{0}{2}$ & $\begin{array}{l}\hat{a} \\
\infty \\
0\end{array}$ & $\begin{array}{l}0 \\
a \\
\vec{a}\end{array}$ & $\approx$ & $\begin{array}{l}\dot{s} \bar{\sigma} \\
\dot{v} \bar{z}\end{array}$ & $\begin{array}{l}\frac{\tilde{a}}{\tilde{a}} \tilde{a} \\
\tilde{n} \tilde{d} \\
\tilde{n} \tilde{z}\end{array}$ & $\begin{array}{l}\dot{\vec{a}} \\
\tilde{a}\end{array}$ & 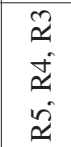 \\
\hline 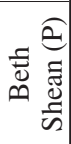 & $\Xi$ & 1 & | & 1 & 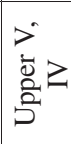 & 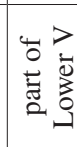 & 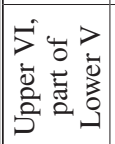 & $\begin{array}{l}5 \\
5 \\
0 \\
0 \\
0 \\
0\end{array}$ & $\begin{array}{l}\dot{\bar{y}} \\
\dot{x}\end{array}$ & 1 & $\begin{array}{l}\dot{x} \mathscr{x} \\
\dot{x}^{\prime}\end{array}$ \\
\hline 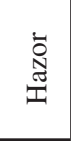 & - & $=$ & 1 & $\begin{array}{l}\text { 三 } \\
2\end{array}$ & $\begin{array}{l}\sum^{5}> \\
\dot{5}=\end{array}$ & $\begin{array}{l}\ddot{x} \\
\ddot{x}\end{array}$ & $\bar{x}$ & $\bar{x}$ & 录 & $\begin{array}{l}\vec{x} \\
\vec{x}\end{array}$ & $\begin{array}{l}\sum_{x} \\
\dot{x}\end{array}$ \\
\hline 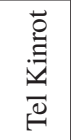 & 1 & 1 & | & 1 & $\Rightarrow$ & ヨ & $\begin{array}{l}2 \\
> \\
5\end{array}$ & | & 1 & $\begin{array}{l}\stackrel{5}{>} \\
\dot{\equiv}\end{array}$ & 罗 \\
\hline $\begin{array}{l}\frac{\pi}{\pi} \\
\frac{\pi}{0} \\
\stackrel{0}{0} \\
\infty\end{array}$ & $=$ & $\Xi$ & 1 & $\geq$ & $\frac{\pi}{j}$ & $\begin{array}{l}\tilde{j} \\
\dot{j}\end{array}$ & $\mid$ & $\mid$ & $\mid$ & 1 & $\mid$ \\
\hline 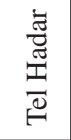 & 1 & 1 & 1 & 1 & 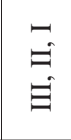 & 1 & $\begin{array}{l}\geq \\
>\end{array}$ & 1 & 1 & 5 & $\mid$ \\
\hline $\begin{array}{l}\overrightarrow{0} \\
0 \\
\text { ज्ञ }\end{array}$ & $\nabla$ & & 1 & $\mid$ & 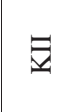 & 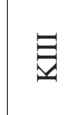 & $\exists$ & 1 & $\mid$ & 1 & $\mid$ \\
\hline $\begin{array}{l}\overrightarrow{0} \\
\stackrel{0}{0} \\
\stackrel{\oplus}{\oplus}\end{array}$ & 5 & 1 & 1 & 1 & $\mid$ & 1 & \multicolumn{2}{|l|}{ F } & $\mid$ & $\stackrel{\Xi}{>}$ & $\mid$ \\
\hline & 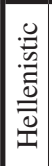 & 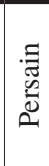 & 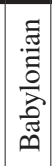 & $\begin{array}{l}0 \\
0 \\
0 \\
0 \\
0 \\
0 \\
0 \\
0\end{array}$ & 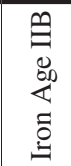 & 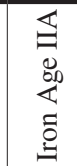 & 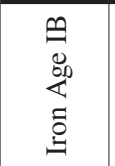 & 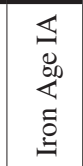 & $\begin{array}{l}\exists \\
\text { ต }\end{array}$ & $\vec{\varphi}$ & $\stackrel{\vartheta}{\Sigma}$ \\
\hline
\end{tabular}


These regional cities are not direct continuations of Canaanite cities or small settlements that developed on hilltops, usually regarded as belonging to the Israelites. Instead, they were established about one hundred years earlier, a phenomenon clearly limited to this region.

If establishing these cities cannot be attributed to the Israelites' activities, the most likely candidate is the ones by the kingdom of Geshur. The Hebrew Bible reports that Geshur existed in the northeastern part of the Sea of Galilee during King David's reign. ${ }^{6}$ That multiple cities were constructed during Iron Age IB (mid-eleventh to mid-tenth centuries BC) in this region, just before the establishment of David's kingdom, is quite noteworthy.

\section{Cities of the Northeastern Sea of Galilee Region and Aram Damascus}

Another common feature of these regional cities is that they experienced major changes between Iron Age IB and IIA. Tel Dover and Tel Hadar were both destroyed at the end of Iron Age IB; a settlement was rebuilt at Tel Hadar during Iron Age IIB but an occupational gap occurred during Iron Age IIA. The cities at Tel 'En Gev and Tel Kinrot were also destroyed and rebuilt according to completely different plans than the former ones, respectively. On the other hand, a new city was built at Tel Bethsaida at this stage. All of these cities persisted with minor rebuilding until the end of Iron Age IIB.

Such drastic changes between Iron Age IB and IIA probably indicate that older cities were destroyed by other groups of people and new cities were built for different purposes. Because the new cities were extremely strong and Aramaic inscriptions are found from the Iron Age IIA stratum, this destruction was presumably related to the southern expansion of Aram Damascus. I Kings 11:23-25 records that when David conquered Aram Zobah, Rezon moved to Damascus and established new rule there. If so, Aram Damascus was already established during the first half of the tenth century BC. ${ }^{7}$ It then possibly grew in strength and became a threat to the Israelites. ${ }^{8}$ Conversely, no reference to the kingdom of Geshur after the reign of King David can be found in

\footnotetext{
${ }^{6}$ Münger $(2013,167)$ points out the similarity between the material cultures of Tel Kinrot and Tel Hadar but hesitates to regard them as belonging to the kingdom of Geshur, because one of the Amarna Letters (EA 256) may refer to locations further inland as Geshur territory. However, it is debated whether EA 256 indeed refers to Geshur. Moreover, it is not certain whether the place names mentioned in the Late Bronze Age text reflect the reality of the Iron Age Geshurite kingdom; thus, these place names cannot be used to define its territory. Münger's identification of Tel Kinrot as late Canaanite is also questionable, because there was a hiatus after the LB I settlement. The material culture of Iron Age IB city is quite different from that of the LB I city. Because Tel Kinrot is located west of the River Jordan, it might have been connected with another Aramaean nation such as Maacha, if it did not belong to Geshur. Yet, it is difficult to differentiate the Aramaean tribal nations based on their material culture.

Berlejung $(2014,341)$ doubts the historicity of this account and some scholars view the expansion of Aram Damascus as late as Hazael's reign (after 842 BC; e.g., Arie 2008, 36-38; Na'aman 2002, 205-244; however, see also Lipiński 2000, 372 who ascribes it to Bar Hadad I [ca. 900-880 BC]). Admittedly, there is little information on the early period of Aram Damascus except a few Biblical references, but considering construction of the new cities during Iron Age IIA, continuation of basic city plans from Iron Age IIA to IIB, and the existence of Aramaic inscriptions from Iron Age IIA stratum, it is quite possible that its expansion occurred earlier. Because other Aramaean nations such as Aram Zobah, Maacha, and Geshur were already established during Iron Age I in the northern Sea of Galilee region, it was probably not difficult for Aram Damascus to extend its rule to this area.

8 Aram Damascus reportedly went to war with Israel many times in the early divided kingdom period (I Kings 15:18-19, chs. 20-22; II Kings chs. 6-8, 13, and 15:37, 16:5-6), although the historicity of these accounts is debated. Aphek, the place mentioned in relation to the battles of I Kings 20 and II Kings 13, is often identified with Tel 'En Gev (Dothan 1975, 63-65; Aharoni 1979, 335, 340, 430; Kochavi 1991, 181; 1992, 47), but this again is not certain (cf. Hasegawa 2012, 501-514). However, the fact that these events are recorded itself reflects that Aram Damascus was perceived as a threat by the Israelites in the beginning of the divided kingdom period. The Tel Dan inscription also reflects conflicts between Aram Damascus and Israel.
} 
the biblical record.

These cities continued until the end of Iron Age IIB, similar to those of Aram Damascus, the northern kingdom of Israel, and the Transjordanian kingdoms until their destruction by the Assyrians. ${ }^{9}$ Notable is that Tel Bethsaida maintained its size while Tel 'En Gev and Tel Kinrot were diminishing. Because the latter two represent conquered old cities and Tel Bethsaida was new in Iron Age IIA, the former may have been constructed for Aram Damascus to rule the former "Geshur" region. ${ }^{10}$

\section{Material Culture of Iron Age Cities in the Northeastern Sea of Galilee Region}

To clarify the nature of the five sites of concern, their material culture is outlined in detail. This facilitates an in-depth evaluation of whether the Iron Age IB cities likely belonged to the kingdom of Geshur, and if the Iron Age IIA-B cities were under the rule of Aram Damascus. Do the material cultures of these cities support such conclusions and what was their relationship with those of neighboring Israelite cities?

\section{Iron Age IIA-B Cities}

Among sites in the northeastern region of the Sea of Galilee, structures from Iron Age IIA-B cities are relatively well-known at Tel Bethsaida and Tel 'En Gev. Analyses of the city layouts and buildings indicate landscapes differing from the Canaanite cities that existed during the Middle and Late Bronze Ages and lasted to the Iron Age I in some parts of the southern Levant. On the other hand, they were similar to Neo-Hittite and Aramaean cities in northern Syria. ${ }^{11}$

Neo-Hittite city states were established in eastern Anatolia and northern Syria after destruction of the Hittite empire around $1200 \mathrm{BC}$. These cities maintained the Luwian cultural tradition. The Aramaeans, who originally adopted pastoral lifeways, also began settling and building cities in northern Syria slightly later than the establishment of Neo-Hittite cities (Millard 1992, 349; Lipiński 2006). ${ }^{12}$ Some Neo-Hittite cities such as Hama, Tell Ahmar (Til Barsib), and Zinçirli ${ }^{13}$ came under Aramaean control. The Aramaeans maintained the Hittite building and sculpture traditions, even after their conquests, probably because they lacked experience in building cities (cf. Dion 1995, 1287). It is therefore difficult to identify "Aramaean" material culture (Novák $2014,255)$ and differentiate it from that of the Neo-Hittites.

Canaanite cities shared several common characteristics both in the northern and southern Levant during the Middle and Late Bronze Age. However, they were already weak during Iron Age I and very few structures were newly constructed, and thus maintained the old tradition. On the other hand, the tradition was reshaped in the Neo-Hittite and Aramaean cities with Luwian

9 Destruction of Iron Age IIA city may be related to the campaign of Shalmaneser III of Assyria, although we cannot date this destruction phase precisely.

${ }^{10}$ My view is different from that of Arav (2004, 6-7), who claims that Bethsaida was the capital of Geshur.

${ }^{11}$ Although it is more desirable to include data from the central and southern Syria in this discussion, excavations from south of Hama are rather limited at this stage.

12 "Aram" originally referred to geographical area rather than ethnicity (Sader 2010, 275-277; Berlejung 2014, 339-341). Whether the Aramaeans were indigenous populations or invaders from outside is debated (Lipiński 2006; Sader 2010, 277; Berlejung 2014, 339).

${ }^{13}$ The University of Chicago excavators, who renewed research at Zinçirli, suggest that it came under a different Semitic group than the Aramaeans (Schloen and Fink 2009, 9-10). 
influence in northern Syria during the same period. It is therefore possible to discuss whether the cities in the northeastern Sea of Galilee region reflect the old Canaanite tradition or newly formed styles of northern Syrian cities.

\section{City Walls}

Casemate walls were unearthed at Tel 'En Gev from Iron Age IIA-B strata in the eastern side of the upper city and southern end of the lower city (Fig. 1). These walls were massive, with widths of $4.5 \mathrm{~m}$; the insides were paved with flagstones, and they supported an artificially raised upper city. Two parallel walls attached to the gate are known at Tel Bethsaida. There were no dividing walls between them but a corridorlike space exists.

Among Canaanite cities in the southern Levant during the Middle and Late Bronze Ages, single, solid walls were usually used. Inset and offset were often added, but casemate walls were rare, ${ }^{14}$ and very few city walls were newly built after the Late Bronze Age. Thus, it is unlikely that city walls in the northeastern region of the Sea of Galilee followed the tradition of Canaanite cities.

In contrast, casemate walls were commonly used in Hittite cities (e.g., Boğazköy, Alishar Hüyük, Kuşakl1) as well as Neo-Hittite (e.g., Carchemish, Tell Tay'inat) and Aramaean cities (e.g., Tell Ahmar, Zinçirli), although single walls were also employed. Double parallel walls similar to those at Tel Bethsaida are also seen in the outer walls of Zinçirli, for example. Thus, the city walls of this region more likely followed the traditions of cities in northern Syria, not those of Canaanite cities. $^{15}$

\section{City Gates}

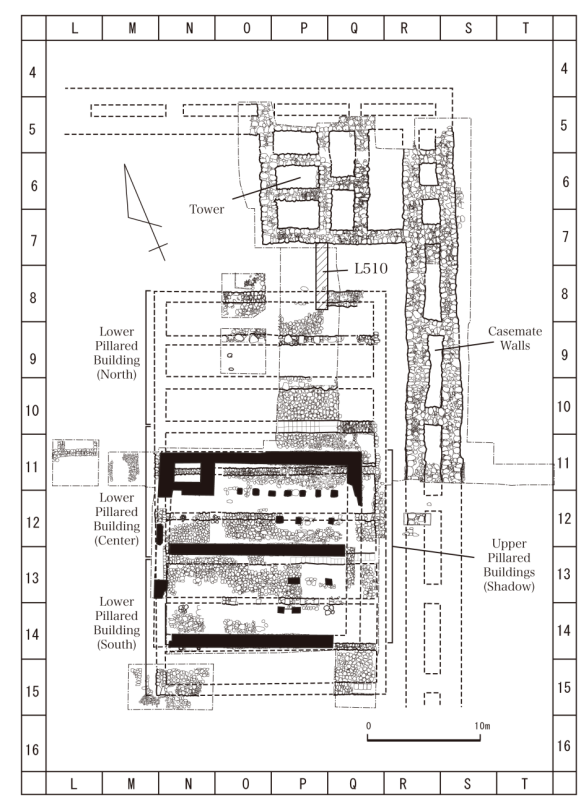

a. 'En Gev: after Tsukimoto et al. 2009, fig. 2-3

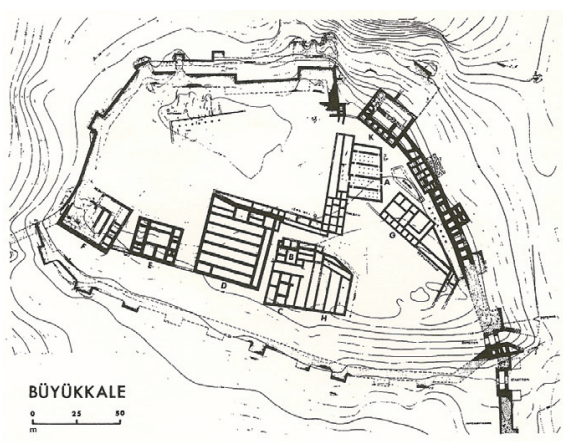

b. Boğazköy: Lampl, 1968, fig. 132

Fig. 1: Casemate Walls and Pillared Buildings

A massive four-“chambered" city gate was unearthed from Str. V of Tel Bethsaida, surrounded by sanctuaries and stelae (Fig. 2a). City gates with one to three pairs of rooms became common in the southern Levant during the Iron Age, and were known as two to six "chambered" gates. They contained rooms and often had benches around them, towers protruding from the façade,

${ }^{14}$ Examples of casemate walls exist from the Middle Bronze Age (e.g., Shechem and possibly Area K at Hazor), but in principle, they did not become popular until Iron Age IIA (see Weippert 1977, 212).

15 The tenth century BC Negev "forts" are often suggested as the origin of the casemate walls (e.g., I. Finkelstein 2000, 126; A. Mazar 1990, 390-397). However, the casemate walls were established even from earlier periods among the Hittites and northern Syrian cities. 
and a bent-axis entryway and plaza in front (Herzog 1992, 271-272). The gate at Tel Bethsaida also has a frontal tower and bent-axis entryway.

In contrast, the city gates popular among Canaanite cities ${ }^{16}$ were so-called four or six "piered" gates (Fig. 2c). These had only two or three pairs of piers protruding from side buildings to the central aisle and differed stylistically, although side buildings were massive and probably often functioned as towers. Furthermore, construction of all types of city gates became quite rare during the Late Bronze Age and Iron Age I in Canaanite cities. ${ }^{17}$

Conversely, numerous city gates were newly constructed in northern Syrian cities during Iron Age I, many of which contained rooms. For example, the southern gate of the inner peripheral wall of Carchemish is a four-"chambered" gate with a pair of frontal towers, resembling the one at Tel Bethsaida (Fig. 2b). ${ }^{18}$ Since there are six and four "piered" gates along this inner wall, the transition to gates with rooms may have been incomplete, but the presence of this new type of gate among the cities in northern Syria is noteworthy. ${ }^{19}$

Seven stelae were found around the city gate at Tel Bethsaida (Arav 2004, 17-34), including one on which was carved a human-like figure with bull's horns resembling a crescent (Fig. 3). In contrast, walls decorated with orthostats are often found around city gates in Neo-Hittite and Aramaean cities (e.g., Carchemish, Karatepe, and Tell Halaf). ${ }^{20}$ However, Bernett and Keel $(1998,42)$ pointed out

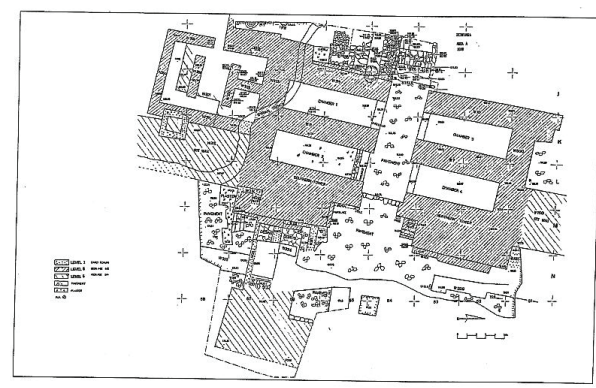

a. Bethsaida: Arav 1999, fig. 1

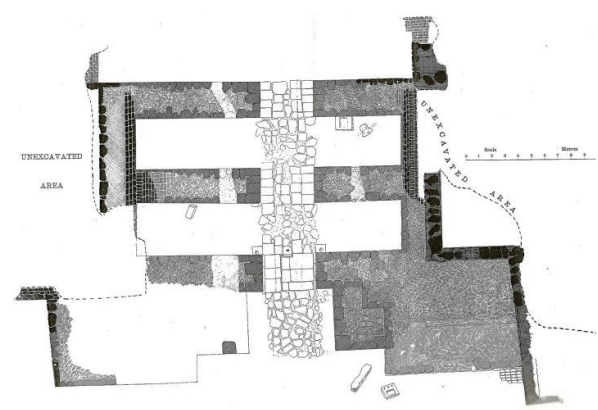

b. Carchemish: Wooley 1921, pl. 12

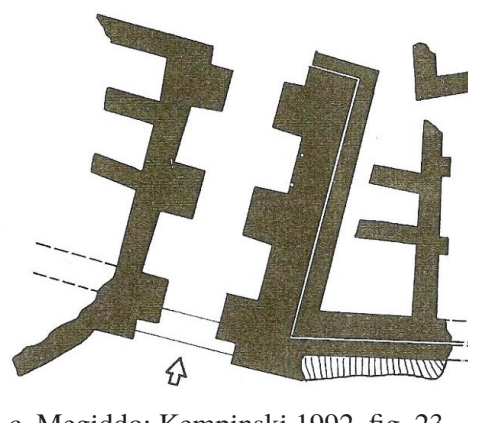

c. Megiddo: Kempinski 1992, fig. 23

Fig. 2: City Gates in the Middle and Late Bronze Ages and Iron Age that this stela with a rounded top and the figure with a crescent crown reflect the relationship with the moon god around Harran in northern Syria, since a similar stela was indeed found at Yarimca near Harran (Lloyd, et al. 1951, Pl. X3). Three more similar stelae were found northeast

${ }^{16}$ This type of city gate was common in Syria and the southern Levant during the Middle and Late Bronze Age (e.g., the south-west gate [Gate A] of Ebla). The Middle Bronze Age gate at Tel Dan has chambers inside, but this gate did not survive until the Late Bronze Age and cannot be the predecessor of Iron Age gates.

${ }^{17}$ The rare city gate constructed during the Late Bronze Age is the one at Tel Rekhesh (Paz et al. 2010). However, this gate is still a six "piered" type and has no chambers.

18 The lower gate of Tel Dan is also similar to these gates (cf. Finkelstein 2000, 125).

${ }^{19}$ Naumann (1971, 279, fig. 14) suggested four stages of city gate development in Anatolia and northern Syria. He indicated that gates with rooms (his third and fourth types) appeared after the destruction of the Hittite empire at the end of the thirteenth century BC, and most examples are from Neo-Hittite, Aramaean, and Assyrian cities.

${ }^{20}$ Concerning the orthostats, see Orthmann 1971 and Gilibert 2011. 
of the Sea of Galilee. ${ }^{21}$ Although these stelae are known only from a particular region in northern Syria, they strongly suggest cultural influence from that region.

\section{Palaces}

A building thought to be a bit hilani palace was unearthed (Fig. 4; Arav and Bernett 2000) from Str. VI at Tel Bethsaida. Having a porticoed façade, a bit hilani is regarded as a palace with Hittite origins in the inscriptions of Sargon II, a king of NeoAssyria (cf. Luckenbill 1927, 42). They are often found among the northern Syrian cities such as Carchemish, Tell Tay'inat, and Zinçirli. However, pillars of excavated buildings are often missing, which makes it difficult to discern whether particular examples such as the one at Tel Bethsaida should really be regarded as bit hilani.

Pucci (2008, 176) studied various palace buildings at Zinçirli, Tell Ta'yinat, and Tell Halaf, and defined bit hilani as a structure with the following elements: two large rooms, running

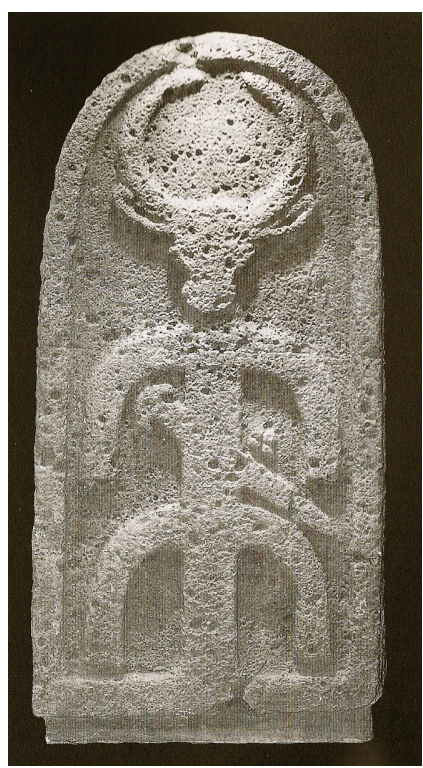

Fig. 3: A Stela from Bethsaida

Arav et al. 2004, 30, fig. 7 parallel; one or two towers flanking the entrance; several smaller rooms behind the second large room; and an entrance portico. The combination of these elements is itself quite peculiar and the plan of the Bethsaida building can be categorized as a bit hilani based on this definition, despite lacking evidence of porticoes. It is stylistically close to Building I at Tell Tay'inat and Palace 6000 at Megiddo.

Novák (2014, 265-267) suggested the presence of two types of palace buildings among Canaanite cities: 1) complex, multi-core buildings with a series of connected apartments, each centered around a courtyard, such as one in Ugarit, ${ }^{22}$ and 2) relatively small units consisting of just a few rooms often without an inner courtyard, such as the one in Alalakh Str. IV. The latter is regarded as the forerunner of the later bit hilani palace, ${ }^{23}$ but such development did not become clear in northern Syrian cities until Iron Age I, as discussed above. If this is the case, the bit hilani palace at Tel Bethsaida does not simply reflect the local Canaanite tradition but rather the new development in northern Syrian cities.

\section{Tripartite Pillared Buildings}

Tripartite pillared buildings are large and rectangular with two rows of stone pillars set parallel to its long axis to divide its interior into three areas. This kind of building is often found in major cities in Israel and Transjordan. In the northeastern Sea of Galilee region, three sets of these buildings are known at Tel 'En Gev from the Iron Age IIA stratum and two from the Iron Age IIB stratum (see Fig. 1).

The function of this building type is unclear, but is generally thought to be for trade

${ }^{21}$ Bernett and Keel 1998, 8-21. See also Wimmer and Khaled 2011.

${ }^{22}$ See the "courtyard palace" in Oren 1992.

${ }^{23}$ Bonfil and Zarzeki-Peleg (2007) claimed that the palace at Hazor is also a forerunner of bit hilani palaces. It has been noted that Hazor was influenced by the Hittites from the Late Bronze Age (e.g., Yadin 1972, 75-87; Shanks 1973). 


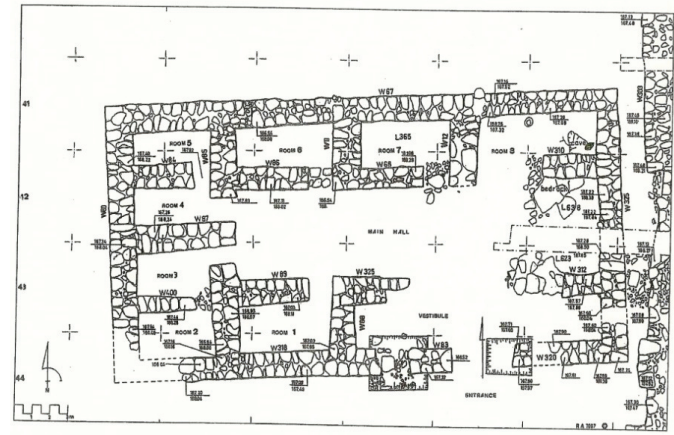

a. Bit Hilani at Bethsaida: Arav and Bernett 2000, fig. 2

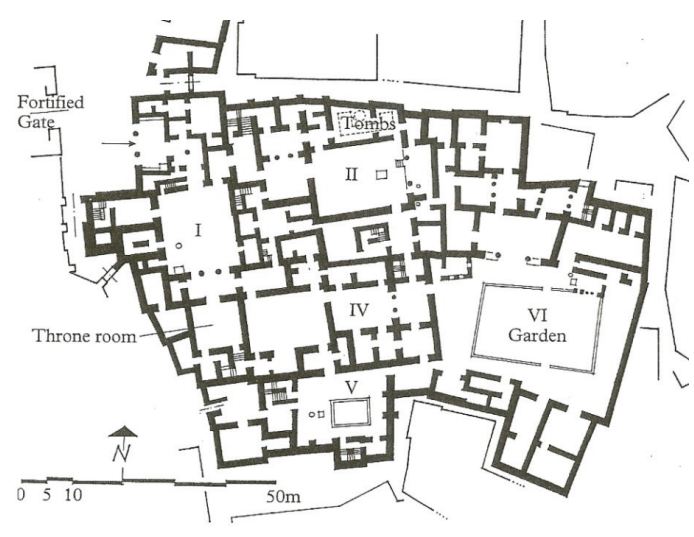

c. Palace at Ugarit:

Akkermans and Schwartz 2003, fig. 10.8

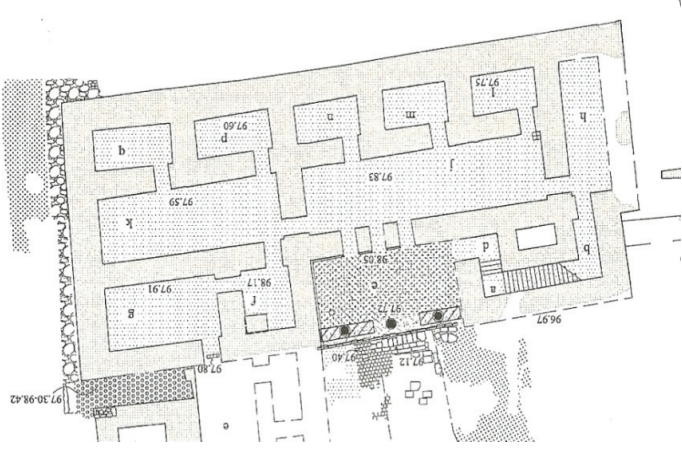

b. Bit Hilani at Tel Tay'inat: after Pucci 2008, pl. 32

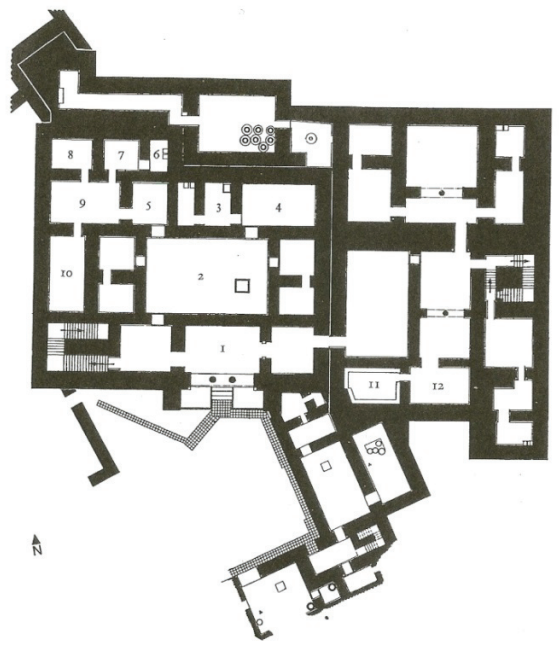

d. Palace in Alalakh Str. IV:

Akkermans and Schwartz 2003, fig. 10. 5

Fig. 4: Bit Hilani Buildings from Iron Age and Palaces from Middle and Late Bronze Ages

(storehouses) or to stable chariot horses (Herr 1988; Kochavi 1998). Its origin is also unknown, but similar buildings are found in a row at Boğazköy, the capital of Hittite kingdoms (Fig. 2), and at Kuşaklı (Müller-Karpe 2000). Although we cannot assume a direct relationship between these limited examples, we know that this building type is completely unknown in Canaanite cities during the Middle and Late Bronze Ages but appeared de novo during these periods.

\section{Pottery}

Pottery from these sites is not well-reported. However, the general assemblages are similar to those from neighboring sites in the southern Levant such as Hazor, Beth Shean, and Megiddo, and likely incorporated the basic local traditions. For example, hole-mouth cooking pots were popular in Syria, ${ }^{24}$ while those with a triangular or pinched rim and carination were dominant in the

${ }^{24}$ For examples from Tell Afis, see Cecchini and Mazzoni 1998, figs. 20:7-9 (level 5, 4), 22:7, 8 (level 3), 25:10 (level 2); and for those from Tell Mastuma, see Iwasaki et al. 2009, fig. 6:21 (cf. 6:22). 
northeastern Sea of Galilee region and other areas in the southern Levant. ${ }^{25}$ Yet, a few pottery types lack southern Levantine parallels. For example, a deep bowl with four or five lines incised outside just below the rim found at Tel 'En Gev (Fig. 5; Sugimoto and Kansha et al. 2010, fig. 5-3) is unknown among the local repertoire but similar examples are reported by Bartl $(1989 ; 1994)$ as pottery from eastern Anatolia.

\section{Inscriptions}

Inscriptions unearthed from these cities also indicate Aramaean presence or influence in this region, considering that examples in west Semitic and Aramaean languages

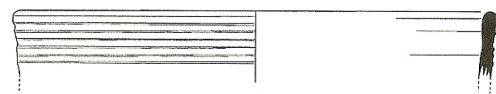

a. 'En Gev: Sugimoto et al. 2010, fig. 5-3

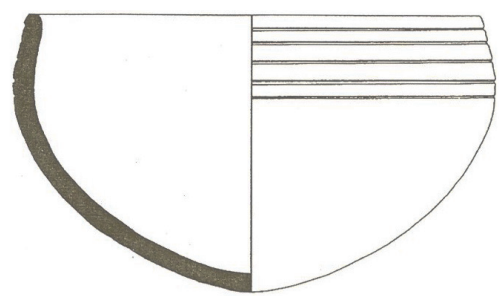

b. Norşun Tepe: Bartl 1994 fig. 6-2

Fig. 5: Bowls with Incised Lines exist. A pottery handle inscribed with $m k y$ and a stamp carved with zkryw were found at Tel Bethsaida. Hess $(2004,55)$ suggested their west Semitic origin and possible association with the biblical names mkyh and zkryh. On the other hand, an ostracon with an Aramaean name ' $q b$ ' (Aquiba) was found at Tel Bethsaida (Arav and Freund 1995, 17-18; Hess 2004, 54) and a vessel inscribed with lšqy' ("for a cup-bearer") in Aramaic was unearthed at Tel 'En Gev (Str. III, Mazar et al. 1964, 27-29, Pl. 13). ${ }^{26}$ Because "cup-bearer" is the title of a high official, this suggests the presence of an Aramaean ruling class in this region, although the exact make-up of the general population is unknown.

\section{Summary}

Based on these discussions, it is clear that the plans and buildings of Iron Age IIA-B cities in the northeastern region of the Sea of Galilee are largely different from those of traditional Canaanite cities, reflecting the styles newly developed in northern Syrian cities. Everyday items such as pottery seem to reflect the local tradition, but even in this area, a hint of connection with northern Syrian cities is evident. If Iron Age IIA-B cities are related to the southern expansion of Aram Damascus, ${ }^{27}$ as suggested above, it is quite natural that their material culture shares common features with that of northern Aramaean and Neo-Hittite cities.

\section{Iron Age IB Cities}

Unlike in Israel, cities already existed in the "Geshur" region during Iron Age IB. Their early establishment is reflected by city walls and large buildings at Tel Hadar, Tel 'En Gev, and Tel Kinrot. Although the city layouts and buildings of this period are less understood as those from

\footnotetext{
${ }^{25}$ For example, concerning the pottery assemblage from Tel Bethsaida, see London and Shuster 1999, and that from Tel 'En Gev, see Sugimoto 2009a.

${ }^{26} \mathrm{Cf}$. also the fragmentary inscription from Tel Hadar, Str. I.

${ }^{27}$ Finkelstein $(2000,125)$ suggested the possibility that Iron Age IIA buildings at Tel 'En Gev were built by the Omrides of Israel. However, in view of the building styles related to the northern Syrian cities, Aramaic inscriptions from Iron Age IIA stratum, and continuation of the basic city plans between Iron Age IIA and IIB, they were more likely built by the Aramaeans. Although straight casemate walls were found at Tel 'En Gev, it is not clear whether they formed a rectangular royal enclosure. Even if they did, the casemate walls at 'En Gev differ from the ones at Samaria and Jezreel in not using ashlars and rectangular royal enclosures are not limited to the Omride constructions (cf. Arslan Tash, Tell Ahmar, Ramat Rachel). Our dating is also different from his Low Chronology (see no. 31 below).
} 
Iron Age IIA-B, general city plans are nonetheless known at Tel Hadar and Tel Kinrot.

Although city walls were not the casemate type at Tel Hadar, Tel 'En Gev, and Tel Kinrot, the excavators report that the city plan at Tel Hadar was set in two concentric circles with peripheral walls (Fig. 6; Kochavi 1993; 1994). The similar combination of a citadel (acropolis) and lower city is also known at Tel Kinrot (Str. V). Two concentric city plans were unknown among Canaanite cities, and citadels themselves were rare. In contrast, Novák (2014, 262-263) pointed out their popularity among Hittite and Aramaean cities (e.g., Alishar Hüyük and Zinçirli; see Naumann 1971, 205-221; Akkerman and Schwarz 2003, 368; Pucci 2008, 171-172). ${ }^{28}$

Two tripartite pillared buildings and two storehouses were unearthed together at the Iron Age IB city of Tel Hadar (Kochavi 1993, 551, fig. bottom left) and Tel Kinrot yielded one pillared building. Although it is hard to establish a clear relationship between this type of building and the northern Syrian tradition, it is completely unknown from Canaanite cities.

Münger (2013, 153-154) highlighted the similarity in layouts of residential buildings at Tel Kinrot with northern Syrian architecture. Intramural internment found at Tel Kinrot (Münger 2013, 162-163) is also a tradition of Mesopotamia and northern Syria (see Akkermans and Schwartz 2003, 381f; Wada 2009, 328-333 for Tell Mastuma and Abou Assaf 1969 for Tell Ashtara).

Pottery assemblages from these sites resemble local ones, but some vessel types hint at a partial connection to the north. For example, amphora-like storage jars cannot be found in the Canaanite tradition, but were unearthed in large quantities from Tel Hadar, Tel 'En Gev, Tel Dover, and Tel Kinrot around the Sea of Galilee (Fig. 7). Münger (2013, 157-161) has already mentioned their connections to northern Syrian sites. A short cylindershaped vessel with a flat base known from Tel Kinrot (Münger 2013, 156) and Tel 'En Gev, ${ }^{29}$ is a common type in northern Syrian sites such as Kamid el-Loz and Ras

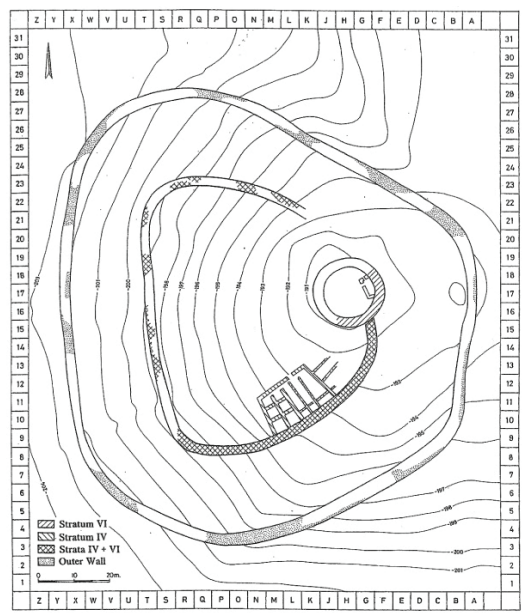

a. Tel Hadar: Kochavi 1994, fig. 1

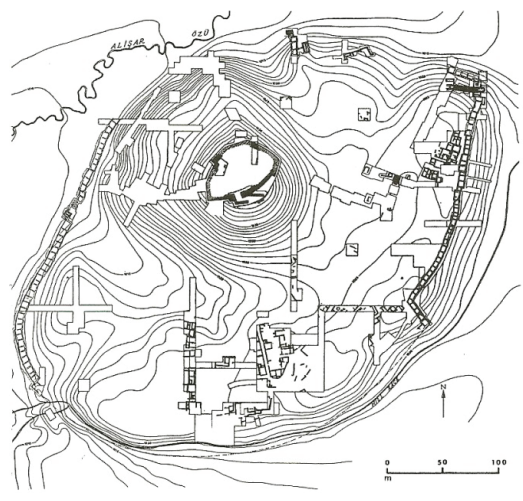

b. Alishar Hüyük:

von der Osten 1937, Pl. I left below

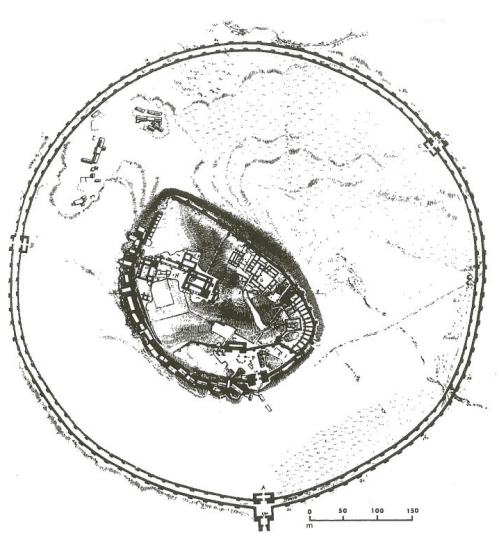

c. Zinçirli: Lampl 1968, fig. 144

Fig. 6: City Plans with Double Concentric City Walls

\footnotetext{
${ }^{28}$ See Bunnens 1995. However, the size of Tel Hadar is much smaller.

${ }^{29}$ See the forthcoming final report.
} 
Shamra.

Regarding cultic artifacts, a large calcite stamp seal was found at Tel 'En Gev. The material and style are local, but the engraved motifs may reflect influence from the northern Syrian tradition (Sugimoto 2014). A specific type of pottery "shrine model" with a cylindrical body and rectangular opening cut into its side are found at Tel Kinrot and Tel Hadar. ${ }^{30}$ This type is only known from Iron Age I sites around the Sea of Galilee and River Jordan (Tel Dan, Tel Hazor, Tell Deir 'Alla, and Tel Zar'a) except a Middle Bronze Age example from Ashkelon. Conversely, the similar "shrine models" are known from Syrian sites from the Late Bronze Age and early Iron Age such as Tell Mumbaqa, Ugarit, and Kamid el-Loz (see Münger 2013, 163-164).

If we correctly assume that the Iron Age IB cities reflect the "kingdom of Geshur," it becomes particularly interesting

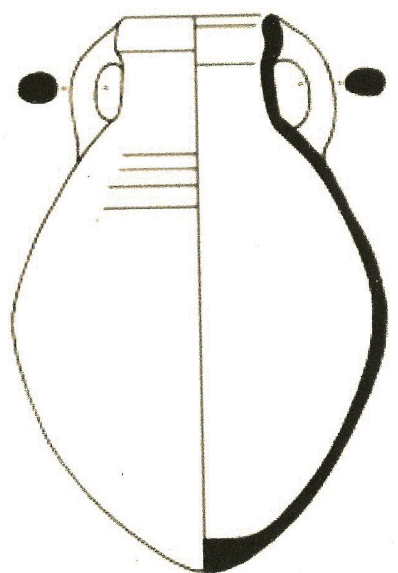

Fig. 7: Amphora-like Storage Jars from the Northeastern Sea of Galilee Region

Tel Kinrot:

Fritz and Münger 2002, fig. 8.2 that three names of its royal family are recorded in the Hebrew Bible (II Samuel 3:3; 13:37), although no inscriptions are found from this period. David's wife is named Maacha, her father Talmai, and her grandfather Ammihud. Maacha and Ammihud are Semitic names, but Talmai is probably Hurrian, meaning "great" (Lipiński 2000, 336; Hess 2004, 56-58). This again indicates the situation in which the local Semitic population and influence from northern Syria coexisted just as during Iron Age IIA-B.

Thus, although the nature of Iron Age IB cities is less known than that of Iron Age IIA-B cities, it still appears quite different from that of Canaanite cities. It is reasonable to assume that Iron Age IB cities in this region were already strongly influenced by the Syrian culture.

\section{Conclusions}

From the discussions above, the following points can be summarized concerning the history and nature of the northeastern Sea of Galilee region:

1. The Iron Age cities were initially constructed during Iron Age IB and completely rebuilt in the beginning of Iron Age IIA. The second cities continued until the end of Iron Age IIB, the time of Assyrian destruction.

2. It is probable that the former reflect the kingdom of Geshur and the latter the southern expansion of Aram Damascus. Tel Bethsaida was probably built by Aram Damascus to rule this region during Iron Age IIA.

3. Although the cities' layout changed significantly, the city plans and buildings of both periods resemble contemporary northern Syrian cities rather than neighboring Canaanite cities.

Iron Age IB cities were established about one hundred years before the construction of Israelite

\footnotetext{
${ }^{30}$ This type can be differentiated from the one with a prominent façade and crafted body part, which are widely found from the Middle Bronze Age to Iron Age I from northern Mesopotamia to southern Levant and developed into an elaborately decorated form during Iron Age II in Phoenicia and Transjordan.
} 
cities. However, Neo-Hittite and Aramaean cities had already been built at the beginning of Iron Age I (ca. 1200 BC) in northern Syria. Because the Aramaeans in northern Syria likely adopted pastoral lifeways early on, they apparently implemented city-building techniques from the NeoHittites. If other groups lacking an urban background such as the Geshurites built cities during Iron Age IB in the northeastern region of the Sea of Galilee, it is reasonable to assume they followed a similar course. Interestingly, they apparently learned no construction techniques from Canaanite cities still remaining during Iron Age I in some southern Levantine areas.

During Iron Age IIA, cities of the northeastern Sea of Galilee region were completely rebuilt and new kingdoms of Israel and Transjordan were constructed. ${ }^{31}$ The kingdom of Geshur allegedly lost its independence and came under the rule of Aram Damascus, but it maintained the same Syrian traditions.

These conclusions have further implications. The city plans and buildings of Iron Age II Israelite and Transjordanian cities are more similar to those of cities in this region and northern Syria than neighboring Canaanite cities. ${ }^{32}$ For example, casemate walls were introduced to Israelite cities in Iron Age IIA (tenth century BC; Herzog 1992; Kempinski 1992). Solid walls were occasionally used later, but the introduction of a new style at this point probably reflects northern influence. Citadels became common and city gates were almost completely changed from having piers to containing chambers, protruding towers, and a bent axis (Herzog 1992; Kempinski 1992). Palace structures in Israel and Judah during Iron Age IIB involved rectangular royal enclosures (e.g., Samaria, Jezreel, Ramat Rachel), while Solomon's palace as described in I Kings 7:13-14 and Palace 6000 at Megiddo during Iron Age IIA are often regarded as bit hilani (e.g., Reich 1992). The Hebrew Bible reports that a three-room fortress temple was built along Solomon's palace (I Kings chs. 5-6; Novák 2014, 267-270), similar to the combination found at the NeoHittite city of Tel Tay'inat (see also the temples at 'Ain Dara and Aleppo). Large pillared buildings were again built in major cities, but are unknown in Canaanite cities.

When the kingdoms of Israel and Transjordan were established and urbanized, they also needed to learn "city culture" from elsewhere. The Israelites likely learned the Syrian styles from north via cities of the northeastern Sea of Galilee region. Perhaps King David's marriage to the daughter of a Geshurite king had both geopolitical and cultural significance. ${ }^{33}$

\section{Bibliography}

Abou Assaf, A. 1969: “Tell Ashtara. 2. Kampagne, 1967,” Annales Archéologiques Arabes Syriennes 19, 101-108.

Aharoni, Y. 1979: The Land of the Bible: A Historical Geography, Philadelphia.

\footnotetext{
${ }^{31}$ Based on the Modified Conventional Chronology, this process should have started from the second half of the tenth century BC (see Sugimoto, forthcoming; Arav also dates Iron Age IIA stratum at Tel Bethsaida [Str. VI] to the tenth century BC). The destruction of the stratum immediately below is dated to the middle of the tenth century $\mathrm{BC}$ at Tel 'En Gev by ${ }^{14} \mathrm{C}$. Pottery from that stratum is similar to that of Iron Age IB stratum at Tel Kinrot (Str. V), which is also dated to $1050 \mathrm{BC}-950 \mathrm{BC}$.

${ }^{32}$ Faust $(2012,230-233)$ criticized the view that Israelites simply inherited the Canaanite culture because their primary pottery forms may have developed from the Canaanite tradition.

${ }^{33}$ The Hebrew Bible reflects strong antagonism against the Canaanites, whereas Aram is remembered as the homeland of patriarchs (e.g., Genesis 24: 2-4; 28: 1-5; Deuteronomy ch.7), in spite of the conflicts between Israel and Aram during the early divided kingdom period. Archaeological data discussed in this paper suggests that this closeness expressed in the Bible may reflect common cultural background between Israel and Aram rather than theological interest.
} 
Albright, W. F. 1943: “Two Little Understood Amarna Letters from the Jordan Valley,” Bulletin of the American Schools of Oriental Research, 89, 7-17.

Albright, W. F. 1956: “'The Biblical Tribe of Massa' and Some Congeners,” in Studi Orientalistici in onore di Giogio Levi Della Vida, Rome, 1-14.

Akkerman P. and G. M. Schwartz 2003: The Archaeology of Syria: From Complex Hunter-Gatherers to Early Urban Societies (ca. 16,000-300 BC), Cambridge.

Arav, R. 2004: "Toward a Comprehensive History of Geshur," in Arav and Freund 2004, 1-48.

Arav, R. and M. Bernett 2000: "The bit hilani at Bethsaida: Its Place in Aramaean/Neo-Hittite and Israelite Palace Architecture in the Iron Age II," Israel Exploration Journal 50/1-2, 47-81.

Arav, R. and R. A. Freund 1995, 1999, 2004, 2009: Bethsaida: a City by the North Shore of the Sea of Galilee, vols. 1-4, Kirksville, Missouri.

Arie, E. 2008: "Reconsidering the Iron Age II Strata at Tel Dan: Archaeological and Historical Implications," Tel Aviv 35, 6-64.

Bartl, K. 1989: "Zur Datierung der altmonochromen Ware von Tell Halaf," in O. M. C. Haex, H. H. Curvers, and P. M. M. G. Akkermans (eds.), To the Euphrates and Beyond, Rotterdam, 257-74.

Bartl, K. 1994: "Die Frühe Eizenzeit in Ostanatolien und ihre Verbindungen zu den Benachbarten Regionen,” Baghdader Mitteilungen 25, 473-518.

Ben-Ami, D. 1981: "The Battle of Aphek, an Israelite Preventive War within the Borders of the Kings of Aram," Eretz Golan 58, 22-32 (Hebrew)

Berlejung, A. 2014: "Outlook: Aramaeans Outside of Syria, 5. Palestine," in H. Niehr (ed.) The Aramaeans in Ancient Syria, 339-365.

Bernett, M. and O. Keel, 1998: Mond, Stier und Kult am Stadttor: Die Stele von Betsaida (et-Tell), (Orbis biblicus et Orientalis 161), Freiburg, Schweitz and Göttingen.

Bonfil, R. and Zarzeki-Peleg, A. 2007: "The Palace in the Upper City of Hazor as an Expression of a Syrian Architectural Paradigm," Bulletin of the American Schools of Oriental Research 348, $25-47$.

Bunnens, G. 1995: "Syro-Anatolian Infulence on Neo-Assyrian Town Planning," Abr-Naharaim Supplement 5, $113-128$.

Cecchini, S. M. and S. Mazzoni 1998: Tell Afis (Siria) Scavi sull' acropolis 1988-1992, Pisa.

Dion, P. E. 1995: “Aramaean Tribes and Nations of First-Millennium Western Asia,” in J. M. Sasson (ed.) Civilazations of the Ancient Near East, Yew York, 1995, 1281-1294.

Dothan, M. 1975: “Aphek on the Israel-Aram Border and Aphek on the Amorite Border,” Eretz Israel 12, 63-65 (Hebrew).

Edelman, D. 1988: “Tel Masos, Geshur, and David,” Journal of Near Eastern Studies 47, 253-258.

Faust, A. 2012: The Archaeology of Israelite Society in Iron Age II, Winona Lake, IN.

Finkelstein, I. 2000: “Omride Architecture,” Zeitschrift des deutschen Palästina-Veriens 116, 114-138.

Fischer, A. A. 2004: Von Hebron nach Jerusalem: Eine redaktionsgeschichtliche Studie zur Einzälung von König David in II Sam 1-5, Berlin.

Fritz, V. 1990: Kinneret: Ergebnisse der Ausgrabungen auf dem Tell el-'Oreme am See Gennesaret, 1982-1985, Abhandlungen des Deutschen Palästina, Wiesbaden.

Fritz, V. 1999: "Kinneret: Excavations at Tell el-Oreimeh (Tel Kinrot): Preliminary Report on the 1994-1997 Seasons," Tel Aviv 26, 92-115.

Fritz, V. and S. Münger 2002: "Vorbericht über die zweite Phase der Ausgrabungen in Kinneret (Tell el 'Oreme) am See Gennesaret, 1994-1999," Zeitschrift des deutschen Palästina-Veriens 118, 2-32.

Gilibert, A. 2011: Syro-Hittite Monumental Art and the Archaeology of Performance, Berlin and New York.

Hasegawa, S. 2012: "Looking for Aphek in $1 \mathrm{Kgs}$ 20," Vetus Testamentum 62, 501-514.

Herr, L. G. 1988: "Tripartite Pillared Buildings and the Market Place in Iron Age Palestine," Bulletin of the American Schools of Oriental Research 272, 47-67.

Herzog, Z. 1992: "Settlement and Fortification Planning in the Iron Age," in Z. Herzog (ed.) The Architecture of Ancient Israel, Jerusalem, 231-274.

Hess, R. S. 2004: “ 'Geshurite' Onomastica of the Bronze and Iron Age,” in Arav and Freund 2004, 49-62.

Iwasaki, T., Wakita, S., Ishida, K., and Wada H. (eds.) 2009: Tell Mastuma: An Iron Age Settlement in Northwest Syria, Tokyo.

Kempinski, A. 1992: "Middle Bronze and Late Bronze Age Fortifications," in Z. Herzog (ed.) The Architecture of Ancient 
Israel, Jerusalem, 127-142.

Kochavi, M. 1989: "The Land of Geshur Project: Regional Archaeology of the Southern Golan (1987-1988 Seasons)," Israel Exploration Journal 39-1/2, 1-17.

Kochavi, M., 1991. “The Land of Geshur Project 1989-1990. Notes and News,” Israel Exploration Journal 41, $180-184$.

Kochavi, M. 1992: "Rediscovered! The Land of Geshur,” Biblical Arachaeology Review 18/4, 30-44, 84.

Kochavi, M. 1993: “Tel Hadar," in E. Stern (ed.), The New Encyclopedia of Archaeological Excavations in the Holy Land, Vol. 2, Jerusalem, 551-552.

Kochavi, M. 1994: "The Land of Geshur Project, 1993," Israel Exploration Journal 44, 136-141.

Kochavi, M. 1998: “The Eleventh Century BCE Tripartite Pillared Building at Tel Hadar,” in S. Gitin, A. Mazar, and E. Stern (eds.), Mediterranean Peoples in Transition: Thirteenth to Early Tenth Century BCE," Jerusalem, 468-478.

Kochavi and E. Yadin 2008: “Tel Hadar," in E. Stern, et al. (eds.), The New Encyclopedia of Archaeological Excavations in the Holy Land, Vol. 5, Jerusalem, 1756-1757.

Lampl, P. 1968: Cities and Planning in the Ancient Near East, New York.

Lipiński, E. 2000: The Aramaeans: Their Ancient History, Culture, Religion (Orientalia Lovaniensia Analecta 100), Leuven.

Lipiński, E. 2006: On the Skirts of Canaan in the Iron Age: Historical and Topographical Researches (Orientalia Lovaniensia Analecta 153), Leuven.

Lloyd, S., W. Brice, C. J. Gadd 1951: “Harran,” Anatolian Studies 1, 77-111.

London G., and R. Shuster 1999: "Bethsaida Iron Age Ceramics," in Arav and Freund 1999, 175-224.

Loud, G. 1948: Megiddo II (Oriental Institute Publications 62), Chicago (= Meggido II).

Luckenbill, D. 1927: Ancient Records of Assyria and Babylonia 1, Chicago.

Mazar, A., 1990: Archaeology of the Land of the Bible: ca. 10,000-586 B.C.E., New York, NY.

Mazar, A., 2005: "The Debate over the Chronology of the Iron Age in the Southern Levant," in T. E. Levy and T. Higham (eds.), The Bible and Radiocarbon Dating, London: Equinox, 15-30.

Mazar, B., A. Biran, M. Dothan, and I. Dunayavsky 1964: “Ein Gev Excavaions in 1961,” Israel Exploration Journal 14/1-2, 1-33.

Millard, A. R. 1992: “Arameans,” in D. N. Freedman, (ed.), Anchor Bible Dictionary, Vol. I, 345-350.

Müller-Karpe, A. 2000: “Untersuchungen in Kuşaklı 1999," Mitteilung der deutschen Orient-Gesellschaft 132, 311-353.

Münger, S. 2013: "Early Iron Age Kinneret-Early Aramaean or Just Late Canaanite? Remarks on the Material Culture of a Border Site in Northern Palestine at the Turn of an Era," in A. Berlejung and M. P. Streck (eds.), Aramaeans, Chaldeans, and Arabs in Babylonia and Palestine in the First Millennium B.C., Wiesbaden, 149-182.

Münger, S., J. Zangenber, and J. Pakkala 2011: "Kinneret: An Urban Center at the Crossroads—Excavations on Iron IB Tel Kinrot at the Lake of Galikee," Near Eastern Arachaeology 74/2, 68-90.

Na'aman, N. 2002: "In Search of Reality behind the Account of David's Wars with Israel's Neighbors," Israel Exploration Journal 52, 200-224.

Na'aman, N. 2012: “The Kingdom of Geshur in History and Memory," Scandinavian Journal of the Old Testament 26/1, 88-101.

Naumann, R.1971: Architektur Kleinasiens: von ihrem Angangen bis zum Ende der hethitischen Zeit, Tübingen.

Novák, M., 2014: “Architecture,” in H. Niehr (ed.) The Aramaeans in Ancient Syria, Leiden, 255-271

Oren, E. D. 1992: "Palaces and Patrician Houses in the Middle and Late Bronze Ages," in A. Kempinski and R. Reich (eds.), The Architecture of Ancient Israel: From the Prehistoric to the Persian Periods, Jerusalem, 105-120.

Orthmann, W. 1971: Untersuchungen zur späthethitischen Kunst (Saarbrücker Beiträge zur Altertumskunde 8), Bonn.

Pakkala, J. 2010: “What Do We Know about Geshur?” Scandinavian Journal of the Old Testament 24, 155-173.

Pakkala, J. 2013: "The Methodological Hazards in Reconstructing the So-called Kingdom of Geshur," Scandinavian Journal of the Old Testament 27, 226-246.

Paz, I., M. Okita, A. Tsukimoto, S. Hasegawa, S.-K Lim, D. T. Sugimoto, T. Onozuka, Y. Tatsumi, M. Yamafuji 2010: "Excavations at Tel Rekhesh," Israel Exploration Journal 60, 22-40.

Pucci, M. 2008: Functional Analysis of Space in Syro-Hittite Architecture (British Archaeological Reports 1738), Oxford. Rapuano, Y. 2001: ‘Tel Dover,' Hadashot Arkheologiyot: Excavations and Surveys 113, 19*-21*.

Reich, R. 1992: "Palaces and Residences in the Iron Age," in Z. Herzog (ed.) The Architecture of Ancient Israel, Jerusalem, 202-222. 
Sader, H. 2010: "The Aramaeans of Syria: Some Considerations on their Origin and Material Culture," in A. Lemaire and B. Halpern (eds.), The Book of Kings: Source, Composition, Historiography and Reception (Vetus Testamentum, Supplements Series 129), Leiden, 273-300.

Schloen, J. D., A. S. Fink 2009: “New Excavations at Zincirli Höyök in Turkey (Ancinet Sam'al) and the Discovery of an Inscribed Morturay Stele," Bulletin of the American Schools of Oriental Research 356, 1-13.

Shanks, H. 1973: "An Incised Handle from Hazor Depicting Syro-Hittite Deity,” Israel Exploration Journal 23, $234-235$.

Sugimoto, D. T. 2009a: "Iron Age Pottery," in A. Tsukimoto, et al. eds. Tel 'En Gev on the Eastern Shore of the Sea of Galilee: Report of the Archaeological Excavations (1998-2004), Tokyo (Japanese), 29-90.

Sugimoto, D. T. 2009b: "The Land of Geshur and the Neo-Hittite Culture," in A. Tsukimoto, et al. (eds.), Tel 'En Gev on the Eastern Shore of the Sea of Galilee: Report of the Archaeological Excavations (1998-2004), Tokyo (Japanese), 195-238.

Sugimoto, D. T. 2010: “"En Gev: Preliminary Report,” Hadashot Arkheologiyot 122, http://www.hadashot-esi.org.il/ report_detail_eng.aspd $=1382 \&$ mag_id=117.

Sugimoto, D. T. 2014: “A Stamp Seal with Complex Religious Motifs from Tel 'En Gev, Israel,” Israel Exploration Journal 64/1, 9-21.

Sugimoto, D. T. forthcoming: "Stratigraphy of Tel 'En Gev, Israel: Correspondence among Three Archaeological Missions," Palestine Exploration Quarterly.

Sugimoto, D. T. and H. Kansha 2010: "Archaeological Excavations at Tel 'En Gev, Israel, 2009, Preliminary Report," Shigaku 79/1-2, 87-114 (Japanese).

Sugimoto, D. T. and H. Kansha 2011: "Archaeological Excavations at Tel 'En Gev, Israel, 2010, Preliminary Report," Shigaku 80/1, 71-89 (Japanese).

Sugimoto, D. T. and H. Kansha 2012: “Archaeological Excavations at Tel 'En Gev, Israel, 2011, Preliminary Report," Shigaku 81/1, 2, 189-222 (Japanese).

Tsukimoto, A., T. Onozuka, and S. Hasegawa (eds.) 2009: Tel 'En Gev on the Eastern Shore of the Sea of Galilee: Report of the Archaeological Excavations (1998-2004), Tokyo (Japanese).

Von der Osten, H. H. 1937: The Alishar Hüyük: Seasons of 1930-32 Parts 3 (Oriental Institute Publications 30), Chicago.

Wada, H. 2009: "Stratum I-1," in T. Iwasaki, S. Wakita, K. Ishida, and H. Wada (eds.), Tell Mastuma: An Iron Age Settlement in Northwest Syria, Tokyo, 303-336.

Weippert, H. 1977: "Mauer und Mauertechnik," in K. Galling, (ed.) Biblisches Reallexikon, $2^{\text {nd }}$ edition, Tübingen.

Wimmer, S. J. and J. Khaled 2011: "Eine Mondgottstelle aus et-Turra/Jordanien," Zeitschrift des deutschen PalästinaVeriens 127/2, 135-141.

Woolley, C. L. 1921: Carchemish II: The Town Defenses, London.

Wooley, C. L. and R. D. Barnett 1952: Carchemish III: The Excavations in the Inner Town: the Hittite Inscriptions, London.

Yadin, Y. 1972: Hazor (The Schweich Lectures 1970), Oxford. 